\title{
HUBUNGAN ANTARA KONSEP DIRI DENGAN KEBERMAKNAAN HIDUP PADA PASIEN GAGAL GINJAL KRONIK YANG MENJALANI TERAPI HEMODIALISIS
}

\author{
Nadya Savitri dan Ratna Supradewi \\ Fakultas Psikologi, Universitas Islam Sultan Agung Semarang \\ Email : supradewi@unissula.ac.id
}

\begin{abstract}
Abstrak
Penelitian ini bertujuan untuk mengetahui hubungan antara konsep diri dengan kebermaknaan hidup pada pasien gagal ginjal kronik yang menjalani terapi hemodialisis. Subjek dalam penelitian ini yaitu pasien gagal ginjal kronik yang menjalani terapi hemodialisis, berjumlah 50 subjek. Teknik pengambilan sampell menggunakan simple random sampling. Pengumpulan data menggunakan skala kebermaknaan hidup dengan indeks diskriminasi aitem yang bergerak dari 0,258-0,671 dengan $\alpha=0,842$ dan skala konsep diri dengan indeks diskrimasinasi aitem yang bergerak antara 0,282-0,557 dengan $\alpha=0,760$. Penelitian ini menggunakan metode kuantitatif korelasional dan menggunakan analisis data statistik product moment. Berdasarkan hasil analisis statistik diperoleh nilai $R_{x y}=0,573$ dengan taraf signifikansi $p=0,000(p<0,01)$. Hasil penelitian menunjukkan bahwa ada hubungan signifikan antara konsep diri dengan kebermaknaan hidup pada pasien gagal ginjal kronik yang menjalani terapi hemodialisis. Adapun mengenai kontribusi konsep diri terhadap kebermaknaan hidup (r2) sebesar 0,328. Hal tersebut mengindikasikan bahwa konsep diri mempengaruhi kebermaknaan hidup sebesar $32,8 \%$ dan sisanya $67,2 \%$ berada di faktor lain yang tidak diteliti pada penelitian ini.
\end{abstract}

Kata Kunci : Kebermaknaan Hidup, Konsep Diri

\section{RELATIONSHIP BETWEEN SELF-CONCEPT WITH MEANINGFULNESS OF LIFE IN CHRONIC KIDNEY FAILURE PATIENTS WHO UNDERGRO HEMODIALYSIS THERAPY}

\begin{abstract}
This study aims to determine the relationship between self-concept with meaningfulness of life in patients with chronic kidney failure who undergo hemodialysis therapy. Subjects in this study were patients with chronic renal failure who underwent hemodialysis therapy, total of the subject were 50 patients. The sampling technique used simple random sampling. Data collection used life-meaning scale with coefficient of item-total correlation from 0,258-0,671 with $\alpha=0,842$ and self concept scale with coefficient of item-total correlation from 0,2820,557 with $\alpha=0,760$. This research used correlational quantitative method and product moment statistical data analysis. Based on the statistical analysis of the results obtained by the value of Rxy $=0.573$ with a significance level of $p=0.000(p<0.01)$. The results showed that there was a significant correlation between self-concept and meaningfulness of life in patients with chronic kidney failure who underwent hemodialysis therapy. As for the contribution of self-concept to the meaningfulness of life $(r 2)$ of 0.328 . This indicated that self-concept affected the meaningfulness of life by $32.8 \%$ and the remaining $67.2 \%$ were in other factors not examined in this study.
\end{abstract}

Keywords: Meaningfulness Of Life, Self Concept 
Hubungan Antara Konsep Diri Dengan Kebermaknaan Hidup Pada Pasien Gagal Ginjal Kronik Yang Menjalani Terapi Hemodialisis

Proyeksi, Vol. 13 (2) 2018, 208-217

\section{Pendahuluan}

Ginjal memiliki fungsi sebagai pengatur keseimbangan kandungan kimia dalam darah. Gagal ginjal merupakan kondisi dimana ginjal kehilangan kemampuan untuk menyaring sisa-sisa makanan dan air dalam tubuh. Apabila kondisi ini terjadi, kadar cairan berbahaya dan racun akan terkumpul di dalam tubuh. Gagal ginjal kronik merupakan kondisi di mana penurunan fungsi ginjal secara tetap dan ukuran ginjal yang menyusut. Penyakit ginjal tahap akhir (PGTA) atau gagal ginjal kronik (GGK) adalah penyakit yang sulit disembuhkan dan bersifat tidak dapat pulih kembali (Setyaningsih, 2011)

Perkembangan gagal ginjal yang bersifat progresif, lambat, dan biasanya berlangsung satu tahun merupakan ciri dari gagal ginjal kronik. Ginjal kehilangan kemampuan mempertahankan komposisi dan volume cairan tubuh. Penyebab gagal ginjal antara lain usia, jenis kelamin, riwayat penyakit seperti diabetes, hipertensi, maupun penyakit gangguan metabolik lain yang dapat menyebabkan penurunan fungsi ginjal. Selain itu kebiasaan merokok dan penggunaan minuman suplemen energi juga dapat menjadi penyebab terjadinya gagal ginjal (Pranandari \& Supadmi, 2015).

Gagal ginjal kronik merupakan menurunnya fungsi ginjal yang terjadi dalam waktu lebih dari 3 bualan. Penyakit gagal ginjal kronik juga dapat terjadi apabila nilai GFR kurang dari $60 \mathrm{ml} / \mathrm{menit} / 1,73 \mathrm{~m}$, yang berlangsung selama lebih dari 3 bulan. Hal tersebut dapat berlangsung dengan atau tanpa kerusakan ginjal. Tahapan gagal ginjal kronik didasarkan pada faal ginjal yang masih tersisa, yang dapat diukur dengan klirens kreatin. Pada penyakit ginjal kronik stadium $\mathrm{V}$ dengan tes kreatinin menunjukan kurang dari $15 \mathrm{ml} / \mathrm{menit} / 1,73 \mathrm{~m}$ dianjurkan untuk menjalani terapi pengganti agar dapat bertahan hidup dengan kualitas baik. Salah satu terapi pengganti yang dilakukan adalah hemodialisis (NA, Panggabean, Lengkong VM, \& Chistine, 2012).

Hemodialisis (HD) adalah prosedur yang dilakukan dengan cara darah dikeluarkan dari tubuh pasien kemudian beredar dalam sebuah mesin dialiser. Kekerapan tindakan hemodialisa beragam, bergantung pada seberapa banyak fungsi ginjal yang tersisa. Pasien rata-rata menjalankan dua kali dalam sepekan, sedangkan lama HD tiga sampai empat jam setiap sekali tindakan terapi (Supriyadi, Wagiyo, \& Ratih, 2011). Terapi hemodialisis membutuhkan waktu 4-5 jam akan menyebkan kelelahan fisik, seperti sakit kepala, serta tekanan darah yang menurun menyebabkan kerigat dingin pada pasien. Hemodialisis juga mempengaruhi keadaan pasien secara psikologis. Pasien gagal ginjal akan mengalami gangguan proses berfikir, konsentrasi, serta gangguan dalam hubungan sosial.

Berdasarkan data dari Indonesian Renal Registry, penerita gagal ginjal mengalami peningkatan pada setiap tahun. Terapi hemodialisis membutuhkan waktu 4-5 jam akan menyebabkan kelelahan fisik, seperti sakit kepala, serta tekanan darah yang menurun menyebabkan keringat dingin pada pasien. Hemodialisis juga mempengaruhi keadaan pasien secara psikologis. Pasien gagal ginjal akan mengalami gangguan proses berfikir, konsentrasi, serta gangguan dalam hubungan sosial. Kondisi tersebut menyebabkan menurunnya kualitas hidup pasien gagal ginjal yang melakukan terapi hemodialisa (Supriyadi, Wagiyo, \& Ratih, 2011)

Permasalahan psikologis yang dialami penderita penyakit ginjal kronik ditunjukkan dari awal individu didiagnosa gagal ginjal kronik. Beberapa individu merasa frustasi, marah, putus asa, dan merasa tidak percaya akan diagnosis dokter. Pada beberapa individu mengaku diliputi rasa cemas, khawatir, dan adanya perasaan takut mati. Beberapa individu juga enggan melakukan aktivitas dikarenakan merasa sudah tidak berguna, mengalami penurunan nafsu makan, gangguan tidur, serta penurunan minat sosial dikarenakan penyakit yang dialami. Semenjak divonis gagal ginjal beberapa individu merasa hidupnya berada dala ketidakberuntungan, tidak memilki harapan, sensitif terhadap 
saran dan ritik (Romadhoni \& Setyawati, 2013) Hal tersebut yang menjadi alasan atau penyebab seorang penderita gagal ginjal kronik akan kebingungan dalam menentukan konsep dirinya serta menjadi kurang memiliki makna hidup.

Hasil wawancara peneliti dalam survey pendahuluan dengan tiga pasien gagal ginjal kronik, peneliti menemukan bahwa konsep diri pasien gagal ginjal kronik cenderung negatif seperti : Subjek Pertama : pasien gagal ginjal kronik bernama $\mathrm{H}$, berjenis kelamin laki-laki, berusia 18 tahun, lama sakit 3 tahun. Wawancara dilakukan pada tanggal 14 oktober 2016. Subjek mengatakan kepada peneliti bahwa :

"Aku divonis gagal ginjal kronik tiga tahun lalu mbak..., awal kelas satu SMA,,, dari awal aku selalu tertutup dengan teman- temanku mbak,,, aku tetep brangkat sekolah kayak biasa cuma kalau jadwal hd aku ijin.,. tetem-temen ga tau aku sakit apa.,, soalnya aku ga mau cerita masalah sakitku... aku juga jarang main sama temen-temen... merasa ga beguna... jadi aku lebih sering sendiri, walaupun aku tetep ingin berjuang tapi aku masih belum bisa terbuka sama orang lain, aku juga sempet berfikir kenapa tuhan nyiptain aku kalau akhirnya aku kaya gini... merasa ga punya masa depan.. ya hidupku yaa ngallir gitu ajaa ga ada semangat semangatnya... terus kadang juga bosen minum obatnya,,, soalnya aku ga bisa lepas dari obat obatan,, kadang juga capek kalau mesti hd kan lamaa waktunya..."

Subjek kedua : pasien gagal ginjal kronik tersebut bernama 0 , berjenis kelamin perempuan, berusia 20 tahun, lama sakit 1 tahun. Wawancara dilakukan pada 20 Maret 2017. Subjek mengatakan kepada peneliti bahwa :

"Pas di vonis gagal ginjal kronik aku biasa aja mbak, karena ngak ngerti gagal ginjal kronik itu apa,,, karena aku kira cuci darah cukup satu bulan, tapi setelah tau harus dilakukan seumur hidup aku mulai putus asa... mikir bakal mati cepet,,, menghindar dari temen-temen, soalnya penampilan fisik juga berubah baget,, jadi minder ga mau ketemu temen-temen atau orang baru... mulai merasa ga punya masa depan lagi, karena harus berhenti kuliah. Merasa bersalah sama orang tua, karena penyakit ini bikin tabungan pendidikan ludes."

Subjek ketiga : pasien gagal ginjal kronik tersebut bernama W, berjenis kelamin laki-laki, berusia 43 tahun, lama sakit 3 bulan. Wawancara dilakukan pada 15 Maret 2017. Subjek mengatakan kepada peneliti bahwa :

"Aku divonis gagal ginjal kronik tiga bulan lalu mbak,", pas dibilang harus hd saya suka kepikian yang tidak tidak soalnya anak-anak saya masih kecil... kalau denger berita kematian dari temen-temen yang jalanin hd ya saya berfikir harus menyiapkan diri... rasanya seperti nunggu antrian entah cepet atau lambat pati akan tiba waktrunya untuk saya... kadang ga pengen mikirin tapi kepikiran terus... bosen juga harus minum obat setiap hari trus juga ga bebes pergi atau kerja soalnya kan seminggu dua kali harus hd..."

Kesimpulan dari ketiga hasil wawancara yang dilakukan peneliti adalah bahwa peneliti melihat kebermaknaan hidup dari tiga subjek kurang terbentuk dengan baik. Hal tersebut dapat dilihat dari subjek yang enggan melakukan aktivitas dikarenakan merasa sudah tidak berguna, serta penurunan minat sosial dikarenakan penyakit yang dialami.

Kebermaknaan hidup merupakan bagaimana individu menghayati keberadaan dirinya, dirasakan berharga, dapat memberi nilai khusus dan memuat hal-hal yang dianggap penting yang dijadikan tujuan hidup serta menjadikan individu menjadi berarti dan berharga. Menunjukan keberanian dalam menghadapi penderitaan dan memberikan makna pada penderitaan yang dihadapi merupakan salah satu cara untuk mencapai kebermaknaan hidup dengan nilai bersikap (Bukhori, 2012).

210 
Setiap individu mempunyai kesanggupan dalam mengambil pendirian terhadap peristiwa tragis atau penderitaan yang tidak dapat dihindari oleh individu tersebut. Hidup tetap memilki arti (makna) di setiap situasi, bahkan dalam kepedihan dan penderitaan sekalipun. Makna merupakan hal yang dianggap berharga, benar, penting, dan memberi nilai khusus bagi individu. Proses memaknai hidup bisa dilakukan bukan pada saat senang atau bahagia saja, tetapi pasien penyakit gagal ginjal kronik yang hidupnya bergantung pada terapi hemodialisis juga dapat memberikan arti dalam kehidupannya (Romadhoni \& Setyawati, 2013).

\section{Kebermaknaan Hidup}

Koeswara (Bukhori, 2012) berpendapat bahwa kebermaknaan hidup merupakan cara sesorang menghayati keberadaan dirinya, mencakup sesuatu yang berharga dan berarti serta dapat memberi arti khusus pada tujuan hidupnya. Koeswara (1992) mengemukakan faktor-faktor yang mempengaruhi penemuan makna hidup pada individu antara lain :

a. Pekerjaan

Manusia dapat memperoleh makna hidup pada kegiatan bekerja, yang utama tidak pada cakupan luas tetapi pada individu bekerja sampai mampu menangani atau menguasai pekerjaannya.

b. Kehidupan keagamaan dan filsafat sekuler.

Makna hidup dapat ditemukan dalam kehidupan keagamaan dan dapat ditemukan juga dalam persoalan filsafat hidup yang bersifat keduniawian.

c. Keindahan

Seseorang dapat menemukan makna hidup dengan menerima atau pasrah dengan kehidupan yang dialami dengan mejalani atau menikmati kehidupan.

d. Cinta pada sesama

Seseoarang yang memiliki cinta mampu memaknai nilai-nilai kehidupan sehingga seseorang itu mempunyai kekayaan batin. Kekayaan batin merupakan salah satu faktor untuk membentuk makna hidup.

e. Pengalaman

Tahap psikospiritual, pengalaman mempunyai makna yang penting karena pengalaman dijadikan sebagai pedoman untuk seseorang dalam bertindak dan berperilaku.

Frankl (Romadhoni \& Setyawati, 2013), kebermaknaan hidup dimaksudkan agar individu mempunyai komitmen kehidupan yang akan membentuk sebuah kekuatan dalam kehidupannya. Hal tersebut menjadi alasan individu untuk tetap bertahan hidup. Kebermaknaan hidup mampu diaplikasikan pada hasrat untuk menjadi seseorang yang bermanfaat bagi orang lain. Individu yang merasakan hidupnya bermakna, mampu memiliki komitmen untuk hidup lebih maju dan berarti. Eksistensi manusia menurut Frankl terdiri dari 3 faktor:

a. Kebebasan

Kebebasan merupakan sesuatu yang tidak dibatasi oleh faktor non spiritual, insting biologi, atau kondisi ligkungan. Setiap individu memilki kebebasan untuk bagaimana bertingkah laku jika menjadi sehat secara psikologis. Apabila individu tidak memiliki kebebasan dapat mengalami hambatan untuk memenuhi potensi-potensi mereka sendiri serta mengganggu perkembangan individu tersebut. 
b. Spiritualitas

Spiritualitas yaitu suatu konsep yang tidak mudah untuk dirumuskan, tidak dapat dikurangi, serta dijelaskan menggunakan istilah-istilah materil. Spiritualitas tidak dihasilkan atau didapat dari dunia materil, namun dunia meterial dapat mempengaruhi spiritualitas tersebut.

c. Tanggung jawab

Suatu pilihan yang telah dipilih setiap individu harus disertai tanggung jawab setiap individu tersebut. Individu yang sehat akan bertanggung jawab dan menggunakan waktu dengan bijaksana agar menjadi individu yang berkembang.

Selain itu, Crumbaugh dan Maholick (Koeswara, 1992) kebermaknaan hidup memiliki komponen-komponen sebagai berikut:

1. Makna hidup

Makna hidup merupakan hal yang dinilai berharga serta penting oleh seseorang, yang dapat dijadikan tujuan hidupnya karena memberi nilai khusus.

2. Kepuasan hidup

Kepuasan hidup yaitu penilaian individu terhadaap hidupnya, bagaimana seorang individu bisa merasakan kepuasan dalam hidup serta bisa menikmati aktivitas-aktivitas yang dijalani.

3. Kebebasan berkehendak

Kebebasan berkehendak yaitu perasaan mampu mengendalikan kebebasan hidupnya yang didasarkan pada nilai-nilai kebenaran dengan bertanggung jawab pada dirinya.

4. Sikap terhadap kematian

Sikap terhadap kematian merupakan seberapa siap atau bagaimana seseorang berpandangan menghadapi kematian. Orang yang mempunyai kebermaknaan hidup akan membekali dirinya dengan berbuat kebaikan sehingga dalam memandang kematian akan merasa siap untuk menghadapinya.

5. Pikiran tentang bunuh diri

Pemikiran seseorang yang berkaitan dengan problem mengakhiri hidup. Bagi individu yang memiliki makna hidup akan berusaha menghindari keinginan melakukan bunuh diri atau mungkin tidak pernah memikirkannya.

6. Kepantasan hidup

Kepantasan hidup yaitu pandangan seseorang tentang hidupnya, apakah ia merasa bahwa sesuatu yang dialaminya pantas atau tidak.

\section{Konsep Diri}

Hamachek dan Marchago (Rath \& Nanda, 2012) berpendapat konsep diri adalah himpunan persepsi atau titik referensi individu tentang dirinya. Himpunan tersebut dapat meliputi karakteristik dirinya, atribut, kualitas, dan kekurangan yang ada pada dirinya. Deaux, Dane, \& Wrightsman (Sarwono \& Meinarno, 2011) menyatakan konsep diri merupakan kumpulan keyakinan serta perasaan individu mengenai dirinya. Kepercayaan seseorang mengenai dirinya meliputi minat, penampilan fisik, kemampuan, penampilan fisik, bakat dan sebagainya. Sedangkan Papalia, Olds, \& 
Hubungan Antara Konsep Diri Dengan Kebermaknaan Hidup Pada Pasien Gagal Ginjal Kronik Yang Menjalani Terapi Hemodialisis

Proyeksi, Vol. 13 (2) 2018, 208-217

Feldman (2009) mengemukakan konsep diri adalah gambaran total individu terhadap diri sendiri. Gambaran total ini mengenai kemampuan-kemampuan dan trait tentang dirinya.

Senada dengan pendapat Bracken (Sung, 2011) konsep diri merupakan pola respon belajar yang mencerminkan individu dalam mengevaluasi perilaku pengalaman masa lalu dan memprediksi perilaku masa depannya. Konsep diri berkembang dengan cara terorganisir menurut prinsip perilaku.

Menurut Sunaryo (2004), terdapat lima komponen yang terdapat pada konsep diri, yaitu :

a. Gambaran Diri (body image)

Gambaran diri merupakan kumpulan dari sikap individu kepada dirinya.

b. Ideal diri (self ideal)

Persepsi seseorang tentang peilakunya, disesuaikan dengan keinginn individu yang berkaitan dengan harapan, cita-cita, serta keinginan yang dimiliki.

b. Harga Diri (self esteem)

Harga diri merupakan penilaian positif maupun negatif yang dilakukan seseorang terhadap dirinya. Penilaian ini memperliahatkan penolakan, sikap penerimaan, serta menunjukkan bagaimana seseorang percaya bahwa dirinya penting, berharga, mampu, serta berhasil.

c. Peran diri (safe role)

Pola perilaku, sikp, nilai, dan aspirasi yang diharapkan individu berdasarkan posisinya di masyarakat.

d. Identitas diri (self identity)

Kesadaran diri pribadi bersumber dari penilaian serta pengamatan, sebagai sintesis semua aspek konsep diri dan menjadi kesatuan yang utuh.

\section{Metode}

Metode pengumpulan data yang digunakan dalam penelitian ini adalah dengan menggunakan skala. Skala dalam penelitian ini terdiri dari aitem favourable dan unfavourable. Aitem favourable merupakan aitem yang berisi tentang konsep perilaku yang mendukung atribut yang akan diukur. Sedangkan aitem unfavourable merupakan aitem yang isinya bertentangan dengan perilaku yang dikehendaki oleh indikator keperilakuannya (Azwar, 2014). Skala penelitian ini menggunakan empat pilihan jawaban : sangat sesuai, sesuai, tidak sesuai, dan sangat tidak sesuai. Skor yang diberikan untuk tiap aitem favourable adalah 4 jika jawabannya SS, skor 3 jika jawaban S, skor 2 jika jawaban TS, dan skor 1 jika jawaban STS. Skor yang diberikan untuk tiap aitem unfavorable adalah 4 jika jawaban STS, skor 3 jika jawaban TS, skor 2 jika jawaban S, dan skor 1 jika jawaban SS.

Penelitian ini menggunakan dua skala yaitu, skala kebermaknaan hidup dan skala konsep diri. Skala yang pertama yaitu skala kebermaknaan hidup terdiri dari 24 aitem yang diambil berdasarkan komponen-komponen kebermaknaan hidup menurut Crumbaugh dan Maholick (Koeswara, 1992). Komponen-komponen tersebut yaitu a) makna hidup, b) kepuasan hidup, c) kebebasan berkehendak, d) sikap terhadap kematian, e) pikiran tentang bunuh diri, f) kepantasan hidup. Skala yang kedua yaitu skala konsep diri terdiri dari 20 aitem yang disusun berdasarkan komponen-komponen konsep diri Sunaryo (2004) yang terdiri dari a) gambaran diri, b) ideal diri, c) harga diri, d) peran diri, e) identitas diri. Skala konsep diri ini dibuat untuk mengukur positif dan negatif konsep diri pada remaja. 
Uji daya beda aitem menggunakan teknik korelasi Product Moment yang dikembangkan oleh Karl Pearson. Penelitian ini menggunakan koefisien reliabilitas Alpha dari Cronbach untuk mengetahui koefisien reliabilitas. Teknik analisis data yang digunakan dalam penelitian ini menggunakan analisis regresi. Perhitungan statistik dalam penelitian ini menggunakan bantuan SPSS (Statistical Packages for Social Sciences) versi 20.

\section{HASIL}

Uji normalitas dalam peneletian ini menunjukkan hasil sebagai berikut :

\begin{tabular}{ccccccc}
\hline Variabel & Mean & Std Deviasi & KS-Z & Sig & $\mathbf{P}$ & Keterangan \\
\hline $\begin{array}{c}\text { Kebermaknaan } \\
\text { hidup }\end{array}$ & 63,34 & 4,805 & 1,331 & 0,058 & $>0,05$ & Normal \\
$\begin{array}{c}\text { Konsep diri } \\
41,02\end{array}$ & 3,347 & 1,572 & 0,014 & $<0,05$ & Tidak Normal \\
\hline
\end{tabular}

Hasil data yang tidak normal disebabkan beberapa alasan yaitu: data yang ekstrim, nilai mendekati nol, banyaknya aitem yang gugur, dan hadirnya satu atau beberapa keanehan (outlier) yang mungkin menyebabkan normalitas gagal. Berdasarkan uji liniearitas antara keberbaknaan hidup dengan konsep diri diperoleh koefisien $\mathrm{F}_{\text {linier }}=23,480$ dengan taraf signifikansi $p=0,000$ ( $p<0.01$ ). Hal ini menunjukkan bahwa distribusi skor skala kebermaknaan hidup dan konsep diri dalam penelitian liniear atau membentuk sebuah garis lurus yang sama. Uji hipotesis antara konsep diri dengan kebermaknaan hidup diperoleh $r x y=0,573$ dan probabilitas $p=0.000(p<0.01)$. Adapun perolehan sumbangsih konsep diri terhadap kebermaknaan hidup ( $r 2$ ) sebesar 0,328. Hal tersebut mengindikasikan bahwa konsep diri mempengaruhi kebermaknaan hidup sebesar $32,8 \%$ dan sisanya $67,2 \%$ berada pada faktor lain yang tidak diteliti pada penelitian ini

\section{Pembahasan}

Penelitian ini bertujuan untuk menguji apakah terdapat hubungan antara konsep diri dengan kebermaknaan hidup pada pasien gagal ginjal kronik yang menjalani terapi hemodialisis. Hasil uji hipotesis pada penelitian ini menunjukan nilai korelasi $r x y=0,573$ dan probabilitas $p=0,000$ $(p<0.01)$. Adapun mengenai kontribusi konsep diri terhadap kebermaknaan hidup $(r 2)$ sebesar 0,328. Hal tersebut mengindikasikan bahwa konsep diri mempengaruhi kebermaknaan sebesar 32,8\% dan sisanya $67,2 \%$ berada faktor lain yang tidak diteliti pada penelitian ini. Hasil yang diperoleh menunjukkan bahwa terdapat hubungan yang signifikan antara konsep diri dengan kebermaknaan hidup pada pasien gagal ginjal kronik yang menjalani terapi hemodialisis. Artinya semakin positif konsep diri maka semakin tinggi kebermaknaan hidup pasien gagal ginjal kronik yang menjalani terapi hemodialisis. Sebaliknya, apabila konsep diri seorang pasien semakin negatif maka semakin rendah kebermaknaan hidup pasien gagal ginjal kronik yang menjalani terapi hemodialisis. Hasil ini menunjukkan bahwa hipotesis peneliti diterima.

Hasil penelitian ini sejalan dengan penelitian Nafisah (2015), yang menyatakan bahwa terdapat hubungan yang signifikan antara konsep diri dengan kebermaknaan hidup pada pasien diabetes melitus anggota polanis DR. H. Swindi Gubug kabupaten Grobogan. Centi (1993) mendefinisikan konsep diri sebagai gagasan tetang diri yang berisi mengenai bagaimana seseorang melihat tentang dirinya sendiri, bagai mana merasakan dirinya, dan bagaimana menginginkan dirinya sebagaimana yang diharapkan. Rogers (Azahra, 2013) menyatakan bahwa individu yang memilki 
Hubungan Antara Konsep Diri Dengan Kebermaknaan Hidup Pada Pasien Gagal Ginjal Kronik Yang Menjalani Terapi Hemodialisis

Proyeksi, Vol. 13 (2) 2018, 208-217

konsep diri yang positif menganggap dirinya berharga dan cenderung menerima diri sendiri sebagaimana adanya. Sebaliknya, orang yang memilki konsep diri negatif akan menunjukan penerimaan diri yang negatif, serta memilki perasaan kurang berharga sehingga menyebabkan penolakan terhadap diri sendiri.

Pasien gagal ginjal yang memilki konsep diri yang positif cenderung percaya bahwa terapi hemosialisis yang mereka jalani bukan berarti ketidak beruntungan. Brooks dan Emmert (Rahmat, 2007) mengungkapkan bahwa individu yang mempunyai konsep diri positif yakin akan kemampuannya mengatasi masalah dan merasa dirinya setara dengan orang lain. (Bastaman, 2007) menyatakan dengan konsep diri positif, pasien gagal ginjal mampu menemukan kebermaknaan hidup dengan mengubah cara pandang. Sikap pasien yang harus mnjalani terapi hemodialisis yang tidak lagi memandangnya sebagai suatu penderitaan melaikan sesuatu yang harus dilalui untuk memperoleh suatu kesuksesan. Hal ini dapat menunjukkan bahwa makna hidup tidak saja ditemukan dalam keadaan-keadaan yang menyenangkan tetapi juga dapat ditemukan dalam penderitaan sekalipun, selama individu mampu melihat hikmah-hikmahnya.

Menemukan dan memperoleh kebermaknaan hidup sangatlah penting bagi pasien gagal ginjal yang menjalani terapi hemodialisis. Hal tersebut diharapkan dapat memberikan kebahagian serta arahan ketika menghadapi segala kesulitan hidup. Frank (Bastaman, 2007) mengartikan makna hidup merupakan hal-hal yang dianggap penting dan berharga serta membri nilai khusus bagi seseorang sehigga layak dijadikan tujuan utama dalam kehidupan. Bila hal ini berhasil dipenuhi maka seseorang akan merasakan kehidupan yang berarti dan dapat menimpulkan peraaan bahagia.

Hasil analisis data skala kebermaknaan hidup pada pasien gagal ginjal kronik yang menjalani terapi hemodialisis tergolong tinggi. Hal tersebut dapat diketahui dari rentang skor subjek (sesuai mean empirik) berada dalam kategori tinggi yaitu 41,8200. Hasil tersebut berbeda dengan studi pendahuluan yang dilakukan berupa wawancara singkat dengan beberapa pasien gagal ginjal kronik yang menjalani terapi hemodialisis. Hasil wawancara menunjukkan bahwa pasien gagal ginjal kronik yang menjalani terapi hemodialisis cenderung memilki tingkat kebermaknaan hidup yang rendah.

Hasil analisis data skala konsep diri menunjukan bahwa konsep diri pasien gagal ginjal kronik yang menjalani terapi hemodialisis tergolong tinggi. Hal tersebut dapat dilihat dari rentang skor subjek (sesuai mean empirik) yaitu 28,8200 . Hasil tersebut berbeda dengan hasil studi pendahuluan yang telah dilakukan. Studi pendahuluan menunjukan bahwa subjek memiliki konsep diri yang negatif. Perbedaan ini dikarenakan peneliti hanya melakukan wawancara awal pada beberapa pasien dan kurang menyeluruh sehingga belum mewakili subjek di RSI Sultan Agung Semarang.

\section{Kesimpulan}

Berdasarkan penelitian yang telah dilakukan, peneliti mendapat hasil analisis data dan pembahasan yang disimpulkan ada hubungan positif yang signifikan antara konsep diri dengan kebermaknaan hidup pada pasien gagal ginjal kronik yang menjalani terapi hemodialisis, dapat dilihat dari hasil korelasi $\left(r_{x y}\right)$ 0,573 dengan taraf signifikansi 0,000 . Hal ini menunjukkan bahwa semakin positif konsep diri maka semakin tinggi kebermaknaan hidupnya, atau sebaliknya semakin negatif konsep diri maka semakin rendah kebermaknaan hidupnya. 


\section{Saran}

Pasien gagal ginjal kronik yang menjalani terapi hemodialisis sebaiknya mempertahankan percaya diri, optimis, dan selalu berfikir positif terhadap sesuatu, juga terhadap kegagalan yang dialami, sehingga dapat memaknai hidup dengan baik. Peneliti selanjutnya yang hendak meneliti dengan subjek yang sama hendaknya lebih menspesifikkan lama sakitnya, jenis kelamin, serta usia. Peneliti selanjutnya sebaiknya menambah variabel bebas yang lain agar hasil penelitian lebih baik lagi.

\section{Daftar Pustaka}

Azwar, S. (2014). Penyusunan Skala Psikologi. Yogyakarta: Pustaka Pelajar.

Bastaman, H. (2007). Logoterapi : Psikologi untuk Menemukan Makna Hidup dan Meraih Hidup Bermakna . Jakarta: PT. Rajagrafindo Persada.

Bukhori, B. (2012, Januari-Juni). Hubungan Kebermaknaan Hidup dan Dukungan Sosial Keluarga dengan Kesehatan Mental Narapidana. Ad-Din, 4(1), 1-19.

Koeswara, E. (1992). Logoterapi Psikologi Viktor Frankl. Yogyakarta: Kanisius.

NA, L., Panggabean, S., Lengkong VM, J., \& Chistine, I. (2012). Kecemasan pada Penderita Gagal Ginjal Kronik yang Menjalani Hemodialisis di RS Universitas Kristen Indonesia. Media Medika Indonesia, 46(3).

Nafisah. (2015). Hubungan Konsep Diri dengan Kebermaknaan Hidup Pasien Diabetes Melitus Anggota Polanis DR. H. Suwindi Gubug Kabupaten Grobogan. semarang: UIN Walisongo.

Papalia, Olds, \& Feldman. (2009). Human Development Edisi 10 Buku I. Jakarta: Salemba Humanika.

Pranandari, R., \& Supadmi, W. (2015). Faktor Resiko Gagal Ginjal Kronik di Unit Hemodialisis RSUD Wates Kulon Progo. Majalah Farmaseutik, 316-320.

Rath, S., \& Nanda, S. (2012). Understanding the role of gender and academic competene. international journal of research, 1(2).

Romadhoni, M., \& Setyawati, R. (2013). Hubungan Antara Penyesuaian Diri dengan kebermaknaan Hidup pada Penderita Penyakit Ginjal Kronik di RSUD Banyumas. PSYCHO IDEA, 11(1), 11-17.

Romadhoni, M., \& Setyawati, R. (2013). Hubungan Antara Penyesuaian Diri dengan kebermaknaan Hidup pada Penderita Penyakit Ginjal Kronik di RSUD Banyumas. PSYCHO IDEA, 11-17.

Sarwono, S. W., \& Meinarno, E. (2011). Psikologi Sosial . Jakarta: Salemba Humanika.

Setyaningsih, T. M. (2011). Peningkatan harga Diri pada Klien Gagal Ginjal Kronik Melalui Cognitive Behavior Therapy (CBT). . Jurnal Keperawatan Indonesia, 165-170.

Sunaryo. (2004). Psikologi Untuk Keperawatan. EGC penerbit buku kedokteran. 
Hubungan Antara Konsep Diri Dengan Kebermaknaan Hidup Pada Pasien Gagal Ginjal Kronik Yang Menjalani Terapi Hemodialisis Proyeksi, Vol. 13 (2) 2018, 208-217

Sung, K. M. (2011). Self Concept and Coping Skill of Female Early Adolescents in South Korea. The Journal of School Nursing, 1.

Supriyadi, Wagiyo, \& Ratih, S. W. (2011). Tingkat Kualitas Hidup Pasien Gagal Ginjal Kronik terapi Hemodialisis. Jurnal Kesehatan Masyarakat, 6(2), 107-112.

Supriyadi, Wagiyo, \& Ratih, S. W. (2011). Tingkat Kualitas Hidup Pasien Gagal Ginjal Kronik Terapi Hemodialisis. Jurnal Kesehatan Masyarakat, 107 - 112. 